\title{
The Influence Of Education On Early Detection Of Cervical Cancer Against The Level Of Knowledge And Interest Checks Wus Iva In The Working Area Clinics Kuin Raya
}

\author{
Linda Kusumawati ${ }^{1 *}$ \\ ${ }^{1}$ Sari Mulia Academy of Midwifery Banjarmasin,Indonesia \\ *linda_kusumawati@akbidsarimulia.ac.id \\ Sitti Khadijah ${ }^{1}$ \\ ${ }^{1}$ Sari Mulia Academy of Midwifery Banjarmasin,Indonesia \\ Sitti_khadijah@akbidsarimulia.ac.id \\ Novita Dewi Iswandari ${ }^{1}$ \\ ${ }^{1}$ Sari Mulia Academy of Midwifery Banjarmasin,Indonesia \\ Novita_dewi_iswandari@akbidsarimulia.ac.id
}

\begin{abstract}
Objective:To identify the effect education about cervical cancer early detection to women's knowledge and interest for IVA examination at the working area of Kuin Kingdom public health center.

Method:Quantitative research using the quasy experimental method with one group pretest-posttest. The population of 31 women in reproductive age. The sample of the study is done by accidental sampling method. The data analyzed by marginal homogeneity using 5\% significant.

Result:There is an effect of education about cervical cancer early detection to women's knowledge showed by $<0.001 \mathrm{p}=0.05$. There is not effect of education about cervical cancer early detection to women's interest for IVA Examination showed by $0,564>\mathrm{p}=0.05$.

Conclusions:Education about cervical cancer early detection gives effect to women's knowledge but does not give effect to women's interest for IVA Examination at the working area of Kuin Kingdom public health center.
\end{abstract}

Keywords:Education, Knowledge, Interest, IVA Examination

\section{INTRODUCTION}

Cervical cancer or cervical cancer is a cancer that many women have experienced. It is become number one after breast cancer cause of one woman died every one hour [1]. According to the World Health Organization (WHO) in 2013, the incidence of cancer increased from 12.7 million cases in 2008 become 14.1 million in 2012. The prevalence of cancer in Indonesia is quite high. Base on health Research data in 2013, tumor or cancer prevalence in Indonesia is 1.4 per 1000 of the population or about 330,000 people. The is highest is cervical cancer [1].

Cervical cancer prevention efforts can be done by early detection or screening. The simple way is by visual inspection IE 
dropping acetic acid 3-5\%, known as IVA (Visual inspection with acetic acid) or Visual Inspection with Acetic Acid (VIA) [2].

According to Maysaroh (2013), cervical cancer requires a very long process that is between 10 to 20 years to become a cancer after the beginning of an infection [3]. Therefore, it is recommended to women of fertile age who have been had sexual intercourse experiences to conduct an examination of the IVA. The prevalence of women done the IVAis $2.45 \%$. it is far from the $50 \%$ target to30 - 35 years old women in5 years [1].

Based on data from Health Office Banjarmasin in 2015, Puskesmas (public health center) Kuin Raya is has the least visit for IVA comparing to other Puskesmas. A preliminary result of a study on March 15, 2016, the Puskesmas was actively implemented IVA 2008 up to now. But the examination of IVA always decreased. Examination of the IVA is only done on fertile age women the acceptor of AKDR. Clinics do not provide a specific timetable and for the examination of the IVA. Therefore, the examination of IVA was limited to the WUS with the acceptor AKDR. Health workers in Clinics Kuin Kingdom also States never gave extension specifically about IVA examination due to the limited costs and health care personnel. So the society particularly the WUS not know pertinent information early detection of cervical cancer using an examination of IVA. Researchers get a chance and great support from health workers to conduct research in the area of employment Clinics Kuin Kingdom.

According to Notoadmodjo (2007), things that affect the action after the extension i.e. audience get other information and awareness of self. Where it is expected to increase the knowledge and awareness of the cause people will do something in accordance with his/her knowledge [4]. A good knowledge is expected to arise awareness of women to avoid risk factors and early check in [5-7]. Therefore, the discussion about knowledge and interests with 3 WUS to visit Clinics Kuin Kingdom where the retrieved results: first mother said the last JUNIOR HIGH education, first married age 27 years old and only have 1 children. The mother both say last HIGH SCHOOL education, was married first to the age of 18 years and has two children. While the third mother says ELEMENTARY education last, first married age 20 years and had four children. The third mother doesn't know about cervical cancer, cause of 
cervical cancer, cervical cancer symptoms, prevention with an examination of the IVA can be done in clinics Kuin Kingdom, free for those who have health coverage as well as States are not interested in conducting an examination of the IVA on the grounds at this time mom doesn't feel any complaints. Based on the description of the background above, research needs to be done to identify the influence of education on early detection of cervical cancer to knowledge and interest checks WUS IVA in the working area Clinics Kuin Kingdom.

\section{RESEARCH METHODS}

Research method of experimental Quasywith One Group Pretest-Posttest.The population of all the WUS in the Workplace Clinics Kuin Kingdom, sampling technique with Accidental Sampling that is as many as 31 people.Engineering data collection using a questionnaire and analyzed using the Marginal Homogeneity test with a 5\% significant level.

\section{RESULTS}

Table 1. frequency distribution of knowledge Examination WUS

\begin{tabular}{llll}
\multicolumn{4}{c}{ IVA Before Extension } \\
\hline No. & $\begin{array}{l}\text { Knowledge } \\
\text { The Extension }\end{array}$ & $\begin{array}{l}\text { Before } \\
\text { of the }\end{array}$ & $\begin{array}{l}\text { Percentage } \\
(\%)\end{array}$ \\
\hline 1. & Less & 9 & 29 \\
2. & Enough & 17 & 54.8 \\
3. & Good & 5 & 16.1 \\
\hline & The total number of & 31 & 100.0 \\
\hline
\end{tabular}

Based on the data in table 1 Note that from 31 mostly WUS have enough knowledge that is as much as 17 people $(54.8 \%)$, less knowledge of as many as 9 people (29\%) and good knowledge of as many as 5 people $(16.1 \%)$.

\begin{tabular}{|c|c|c|c|}
\hline \multirow[b]{2}{*}{ No. } & \multicolumn{3}{|c|}{ Examination WUS After Extension } \\
\hline & $\begin{array}{l}\text { Knowledge After } \\
\text { Extension }\end{array}$ & $\begin{array}{l}\text { The } \\
\text { frequency of } \\
\text { the }\end{array}$ & $\begin{array}{l}\text { Percentage } \\
(\%)\end{array}$ \\
\hline 1. & Less & 3 & 9.7 \\
\hline 2. & Enough & 11 & 35.5 \\
\hline 3. & Good & 17 & 54.8 \\
\hline & $\begin{array}{l}\text { The total number } \\
\text { of }\end{array}$ & 31 & 100.0 \\
\hline
\end{tabular}

Based on the data in table 2 noted that 31 of the WUS most have good knowledge that is as much as 17 people (54.8\%), knowledge is quite as many as 11 people $(35.5 \%)$ and less knowledge as much as 3 people $(9.7 \%)$.

Table 3. distribution of the frequency of Interest Checks WUS IVA Before Extension

\begin{tabular}{llll}
\hline No. & $\begin{array}{l}\text { Interest Before } \\
\text { The Extension }\end{array}$ & $\begin{array}{l}\text { The frequency } \\
\text { of the }\end{array}$ & $\begin{array}{l}\text { Percentage } \\
(\%)\end{array}$ \\
\hline 1. & Low & 2 & 6.5 \\
2. & High total & 29 & 93.5 \\
\hline & $\begin{array}{l}\text { The } \\
\text { number of }\end{array}$ & 100.0 \\
\hline
\end{tabular}

Based on the data in table 3 Note that from 31 mostly WUS have high interest i.e. as many as 29 people $(93.5 \%)$ and the rest 
with low interest as much as 2 people $(6.5 \%)$.

Table 4. frequency distribution Interest WUS Checks IVA After Extension

\begin{tabular}{llll}
\hline No. & $\begin{array}{l}\text { Interest After } \\
\text { Extension }\end{array}$ & $\begin{array}{l}\text { The } \\
\text { frequency of } \\
\text { the }\end{array}$ & $\begin{array}{l}\text { Percentage } \\
(\%)\end{array}$ \\
\hline 1. & Low & 1 & 3.2 \\
2. & High & 30 & 96.8 \\
\hline & $\begin{array}{l}\text { The total } \\
\text { number of }\end{array}$ & 31 & 100.0 \\
\hline
\end{tabular}

Based on the data in table 4 Note that from 31 mostly WUS have high interest i.e. as many as 30 people $(96.8 \%)$ and the rest with low interest as much as 1 person $(3.2 \%)$.

Table 5. the influence of education on early detection of cervical cancer WUS to knowledge about IVA Examination in the working area Clinics Kuin Kingdom

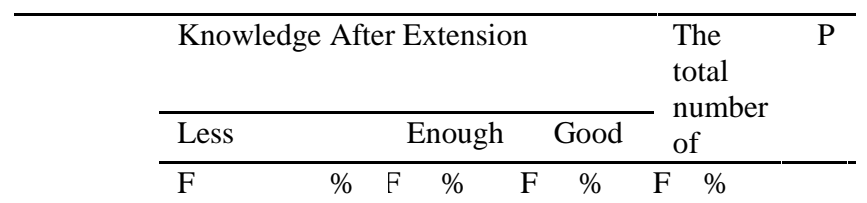

\begin{tabular}{|c|c|c|c|c|c|c|c|c|c|c|}
\hline \multirow{3}{*}{$\begin{array}{l}\text { Knowledge } \\
\text { Before The } \\
\text { Extension }\end{array}$} & Less & 3 & 9.7 & 1 & 3.2 & 5 & 16.1 & 9 & 29 & \multirow[t]{3}{*}{0.001} \\
\hline & Enough & 0 & 0 & 3 & 25.8 & 9 & 29 & 17 & 54.8 & \\
\hline & $\overline{\text { Good }}$ & 0 & 0 & 2 & 6.5 & 3 & 9.7 & 5 & 16.1 & \\
\hline $\begin{array}{l}\text { The total } \\
\text { number } \\
\text { of }\end{array}$ & 3 & & 9.7 & 11 & 35.5 & 17 & 54.8 & 31 & 100 & \\
\hline
\end{tabular}

Based on table 5 shows the results table cross-influence of education on early detection of cervical cancer to knowledge WUS, WUS that have subjects where knowledge is lacking at the time before and after extension as much as 3 people $(9.7 \%)$, the subject of the WUS have less knowledge before and after the extension of the extension into the category of knowledge is quite as much a 1 person $(3.2 \%)$, the subject of the WUS that have enough knowledge at the time before and after extension as much as 8 people $(25.8 \%)$, the subject of the WUS have a high knowledge before and after the extension of the extension into the category of knowledge is quite as much as 2 people (6.5\%), the subject of the WUS that have less knowledge before and after the extension of the extension into the category of good knowledge as many as 5 people (16.1\%), the subject of the WUS that have enough knowledge before and after the extension of the extension into the category of good knowledge as much as 9 people (29\%) and the subject of WUS that have good knowledge at the time before and after extension as many as 3 people $(9.7 \%)$,

Hypothesis test results using the Marginal Homogeneity test obtained p value $=0.001$ results where $\mathrm{p}$ value less than 0.05 Ha which means that it is accepted and Ho is rejected then there is the influence of education on early detection of cervical cancer against knowledge about IVA in Examination WUS working area Clinics Kuin Kingdom. 
Table 6. the influence of education on early detection of cervical cancer WUS interest checks against IVA in the working area Clinics Kuin Kingdom

\begin{tabular}{|c|c|c|c|c|c|c|c|c|c|}
\hline & & & \multicolumn{4}{|c|}{$\begin{array}{l}\text { Interest } \\
\text { Extension }\end{array}$} & \multirow{2}{*}{\multicolumn{2}{|c|}{$\begin{array}{l}\text { The } \\
\text { total } \\
\text { number } \\
\text { of }\end{array}$}} & \multirow{2}{*}{$\mathrm{P}$} \\
\hline & & & \multicolumn{2}{|c|}{ Low } & \multicolumn{2}{|c|}{ High } & & & \\
\hline & & & $\mathrm{F}$ & $\%$ & $\bar{F}$ & $\%$ & $\mathrm{~F}$ & $\%$ & \\
\hline \multirow{2}{*}{$\begin{array}{l}\text { Interest } \\
\text { Before } \\
\text { Extension }\end{array}$} & & Low & 0 & 0 & 2 & 6.5 & 2 & 6.5 & \multirow[b]{2}{*}{0.564} \\
\hline & The & High & 1 & 3.2 & 28 & 90.3 & 29 & 93.5 & \\
\hline \multicolumn{3}{|c|}{ The total number of } & $\overline{1}$ & 3.2 & 30 & 96.8 & 31 & 100 & \\
\hline
\end{tabular}

On the basis of table 6 shows the results table cross-influence of education on early detection of cervical cancer WUS interest checks against IVA, where the subject of the WUS that have high interest before the extension being low interest categories at the time after outreach as much as 1 person $(3.2 \%)$, the subject of the WUS that have low interest in the moment before the extension into high-interest categories after extension as much as 2 people $(6.5 \%)$ and the subject of WUS that have high interest at the moment before or after extension as many as 28 people $(90.3 \%)$.

Hypothesis test results using the Marginal Homogeneity test obtained p value $=0,564$ results in which the values of $p$ greater than $0.05 \mathrm{Ha}$ which means that rejected and Ho is accepted then there is no influence of education on early detection of cervical cancer against interest checks WUS IVA in the working area Clinics Kuin Kingdom.

\section{DISCUSSION}

\section{Knowledge about IVA Examination WUS Before Extension}

Based on the data in table 1 Note that from 31 mostly WUS have enough knowledge that is as much as 17 people $(54.8 \%)$, less knowledge of as many as 9 people (29\%) and good knowledge of as many as 5 people (16.1\%). Most of the respondents have enough knowledge categories, caused by factors of education, environment and age. Another cause that is the limitations of information about early detection of cervical cancer using an examination of IVA, health workers in Clinics Kuin Kingdom does not provide guidance in particular about the early detection of cervical cancer using examination of the IVA. So most WUS knowledge before and after illumination in the category is enough.

It is in accordance with the opinion of Edwin (2009) stating that knowledge is a person's ability to remember facts, symbols, procedures and theory [8]. Knowledge is the result of knowing and this happened after people doing particular against an object sensing. Pendinderaan this 
happens through the five senses of human beings that is the senses of vision, hearing, smell, taste and raba. Most human knowledge is obtained through the eyes and ears. Knowledge or cognitive domain is very important for the formation of the person's behavior ([9]. The research results have researchers did supported the results of research conducted by Meyrianti (2015) that the knowledge of the respondents prior to the extension that is good knowledge as much as 8 people (13.1\%), knowledge of as many as 21 people (cekup 34.4\%) and less knowledge as much as 32 people $(52.5 \%)[10]$.

\section{Knowledge about IVA Examination WUS After Extension}

Based on the data in table 2 noted that 31 of the WUS most have good knowledge that is as much as 17 people $(54.8 \%)$, knowledge is quite as many as 11 people (35.5\%) and less knowledge as much as 3 people $(9.7 \%)$. It is caused by the application of counseling related knowledge about the early detection of cervical cancer using the IVA examination conducted by researchers to Work in the area of the clinic WUS Kuin Kingdom. This indicates that the given extension has an impact to improve the knowledge of WUS.

The results of this research in line with the opinion of the Notoatmodjo (2010) States that one of the external factors to increase public knowledge can also be via methods extension, with increasing one's knowledge will change his mind [9]. In accordance with the theory, according to Ali (2010) is a public health outreach conducted by way of spreading the message, mananamkan belief, so that people are not only aware of, know and understand, but also willing and able to do a the suggestion that have to do with health [11]. It can be concluded that knowledge after the WUS done outreach about the early detection of cervical cancer examination using the IVA is mostly in the category of good compared to prior guidance. But there are still some respondents who are knowledgeable enough and less. It is also in line with the results of the research conducted by Meyrianti (2015) extension that is done after knowledge knowledge of good 54 people $(88.5 \%)$, sufficient knowledge of 5 people (8.2\%) 
and less knowledge of 2 people (3.3\%) [10].

\section{Interest checks WUS IVA Before Extension}

According to Hurloch (1999) that the interest is a source of motivation that drives people to do what they want when they freely choose. This research provides freedom in accordance with the wishes of the respondent, whether the respondent has an interest to perform inspection of the IVA.

Based on the data in table 3 Note that from 31 mostly WUS have high interest i.e. as many as 29 people $(93.5 \%)$ and the rest with low interest as much as 2 people $(6.5 \%)$. In this study almost all respondents have high interest to conduct an examination of the IVA, only 2 respondents who have low interest. The conformity theory and research results here only on the freedom of the desire of the respondent to perform such activities. So it can be inferred that WUS work in the area of public health has a high interest in Kuin Kingdom to perform inspection of the IVA.

\section{Interest checks WUS IVA After Extension}

According to Ali (2010) is a public health outreach conducted by way of spreading the message, invested belief, so that people are not only aware of, know and understand, but also want to and can make an argument that there are relation to health [11]. However in the results of the research carried out before the extension, interest WUS belongs to high it is contained in table 4. Note that of the 31 most WUS have high interest i.e. as many as 30 people $(96.8 \%)$ and the rest with low interest as much as 1 person (3.2\%). The results of the data collection after a researcher doing outreach, obtained results that interest WUS checks IVA increased compared to prior guidance, but there is still 1 still has low interest to do examination of the IVA. Education on early detection of cervical cancer using examination only impacted on the interest of the respondents because the interest before he does counseling almost all respondents have high interest. 


\section{The influence of Illumination against} the knowledge Examination of WUS IVA

Hypothesis test results using the Marginal Homogeneity test obtained $\mathrm{p}$ value $=0.001$ results where $\mathrm{p}$ value less than $0.05 \mathrm{Ha}$ which means that it is accepted and Ho is rejected then there is the influence of education on early detection of cervical cancer against knowledge about IVA in examination WUS working area Clinics Kuin Kingdom. The results of this research show that with the related guidance he gave early detection of cervical cancer using examination IVA by researchers can enhance knowledge WUS that became respondents. Guidance given by the researchers delivered the lecture, $\mathrm{q}$ $\& \mathrm{a}$ and media information leaflet.

An increase in knowledge of the early detection of cervical cancer using an examination of IVA on WUS can be seen from statements the questionnaire answered by respondents. There are 10 statements of knowledge and 8 statement that experience increased knowledge, i.e. on the numbers of problem 1, 3, 4, 5, 6, 7, 9 and 10. Where the statement 8 statement, among others, about the purpose of early detection of cervical cancer, common symptoms of cervical cancer, risk factor for cervical cancer, examination techniques, preparation of the patient prior to the IVA examination examination and implementation of IVA IVA. This illustrates that respondents experienced an increase in knowledge after being given counseling.

The results of this research are consistent with research conducted by Sabtariani (2015) with the title influence adolescent reproductive health counselling to knowledge schoolgirl SMUN 11 Five Continents in North Barito Regency obtained the value of $p$ $=0.001$ then there is influence of counseling about reproductive health of adolescent students to knowledge SMUN 1 five-Continent [12]. By extension it gives related reproductive health by researchers can increase the knowledge of students/teenagers. Other research results selajan i.e. research conducted by Meiriyanti (2015) with the title the influence of illumination towards the knowledge and attitudes of adolescents about premarital sex in high school PGRI 2 Banjarmasin obtained the value of $p=0.000$ then there is 
influence before and after the extension to knowledge of adolescent premarital sex in high school about PGRI 2 Banjarmasin [10].

According to researchers with the extension that has been done can increase the knowledge of the respondent which was previously the largest category on knowledge and, after considerable outreach into the largest category on knowledge either. Although in the delivery of the material and measuring knowledge done the same day, but this already illustrates that the delivery of the material that has been done by researchers can be well received so that respondents know and understand about the education on early detection of cervical cancer using an examination of IVA.

Knowledge of the skrinning of cervical cancer is an important element in determining whether a woman will undergo early detection of pap smear/IVA [13]. This is important in addition to the presence of a cervical cancer screening facility availability in the primary health center [14].

\section{The influence of Illumination towards the Interest checks WUS IVA}

On the basis of table 6 shows the results table cross-influence of education on early detection of cervical cancer WUS interest checks against IVA, where the subject of the WUS done measurement of interest before and after illumination, there are two people $(6.5 \%)$ have low interest and as many as 28 people $(90.3 \%)$ have a high interest.

According to Ali (2010) is a public health outreach conducted by way of spreading the message, mananamkan belief, so that people are not only aware of, know and understand, but also willing and able to do [11]. Hypothesis test results using the Marginal Homogeneity test obtained $\mathrm{p}$ value $=0,564$ results in which the values of $\mathrm{p}$ greater than $0.05 \mathrm{Ha}$ which means that rejected and Ho is accepted then there is no influence of education on early detection of cervical cancer against interest checks WUS IVA in the working area Clinics Kuin Kingdom.

The results of this peneltian are inconsistent with research conducted by Setyowati (2014) entitled the influence of education on woman's interest 
against the age aware of fertile 20-45 years doing breast self Examination (REALIZE) in the hamlet of Bantul Ringin harjo Dune that research results obtained the value of $\mathrm{P}$ (value) $<\mathrm{P}$ value 0.0000 .05 count so there is influence the extension REALIZED against interest do REALIZE before and after illumination [15].

Other studies that are in line with the results of this study, namely the results of research conducted by Nugraheny (2010) with the title influence the granting of extension towards behavior to do early detection of cancer of the cervix reviewed from on high school teacher in Subdistrict of Bantul of Yogyakarta where Sanden obtained results there is no meaningful/significant pegaruh granting of extension towards behavior to do early detection of cervical cancer in terms of age [16]. According to the factors that influence the behaviour of the researcher to probe dinin was employment status and level of education whereas the marital status and age does not affect the behavior of conducting early detection.

Extension of high interest are influenced by the desire of the person's inner self to do a thing. In accordance with the theory presented by Safari (2003) that there are four indicators of interest i.e. the feeling of pleasure, interest, attention and involvement [17]. In this study only measured interest based on measurement results by using the questionnaire statements. Whether from a high interest in this will be a real action of the respondents to conduct an examination of the IVA on Clinics Kuin Kingdom.

Based on the results obtained by the age distribution of the table that the amount of most respondents at the age of 35 years over that is as much as 21 people. Where respondents have high enthusiasm in education on early detection of cervical cancer using an examination of IVA. It can be seen from the internal interests of the respondents is high at the moment before it does the extension that is as many as 29 people from the total number of respondents as many as 31 people. After doing outreach increases to 30 people and there is only 1 person who has an interest. Where 1 person at the moment prior to the extension of high interest and after having done outreach into low interest.This 49-year-old respondents 
who have entered the category of menopause. According to the researchers, the things that cause changes to the respondents the possibility interest caused by changes in mood or anxiety the respondent so as to make the fear of these respondents after receiving low interest into counseling. This is in line with the theory presented by Spencer (2006) that the psychological symptoms during menopause, namely the attitude of irritability, depression, anxiety, mood (mood) the uncertain and difficult concentrating [18].

\section{CONCLUSION}

According to the assumptions of the researcher or no influence in the outcome of the extension made on variable interest, this may be caused by the respondents never get other information, be it through mass media or from the person closest related respondents examination of the IVA. In addition to that person's interests can be affected by the stimulus coming from the environment, the social and emotional factors motifs such as feeling happy, failure, fear, anxiety and so on. Although the results of the outreach has been done does not give much impact, either before or after doing outreach, is expected on the WUS have such high interest to be able to realize those interests by doing examination of the IVA to a clinic.

\section{REFERENCES}

[1].Badan penelitian dan pengembangan kesehatan. Kementrian Kesehatan RI. .Riset Kesehatan DasarTahun 2013. Jakarta. 2013

[2].Prawirohardjo, Sarwono. Ilmu Kandungan. Bina Pustaka. Jakarta. 2012.

[3].Maysaroh, Hanik. .Kupas Tuntas Kanker pada Perempuan dan Penyembuhannya. Klaten: Trimedia Pustaka. 2013

[4].Notoatmodjo, S. Promosi Kesehatan dan Ilmu Perilaku. Jakarta: Rineka Cipta.2007.

[5].Kivistik Alice, Katrin Lang, Paolo Baili, Ahti Anttila and Piret Veerus. Women's knowledge about cervical cancer risk factors, screening, and reasons for nonparticipation in cervical cancer screening programme in Estonia. BMC Women's Health. 11:43. 2011. 2-6.

[6]. Aswathy S, Mariya Amin Quereshi, Beteena Kurian \& Leelamoni K. Cervical Cancer Screening: Current Knowledge \& Practice Among Women In A Rural Population Of Kerala, India. Indian $\mathrm{J}$ Med Res 136. 2012. 205-210.

[7].Al-Meer F.M, Aseel M.T, J. AlKhalaf, Al-Kuwari M.G. and Ismail. Knowledge, attitude and practices regarding cervical cancer and screening among women visiting primary health care in Qatar. 
Eastern Mediterranean Health Journal Vol. 17 (11). 2011. 855-861.

[8].Edwin, BFlippo. Manajemen Personalia Jilid I. Jakarta: Erlangga. 2009.

[9].Notoatmodjo S. Metodologi Penelitian Kesehatan. Jakarta: Rineka Cipta.2010.

[10]. Meiriyanti, Putri. Pengaruh Penyuluhan Terhadap Pengetahuan dan Sikap Remaja Tentang Seks Pranikah di SMA PGRI 2 Banjarmasin [Skripsi]. Sekolah Tinggi Ilmu Kesehatan Sari Mulia Banjarmasin. 2015.

[11]. Ali, Z., Dasar-Dasar Pendidikan Kesehatan Masyarakat dan Promosi Kesehatan. Jakarta: Trans Info Media. 2010.

[12]. Sabtariani. Pengaruh Penyuluhan Kesehatan Reproduksi Remaja Terhadap Pengetahuan Siswi SMUN 1 Benua Lima Kabupaten Barito Timur [Skripsi]. SekolahTinggi Ilmu Kesehatan Sari Mulia Banjarmasin. 2015.

[13]. Sharron SK Leung, Ivy Leung. Cervical cancer screening: knowledge, health perception and attendance rate among Hong Kong Chinese women. International Journal of Women's Health :2 . 2010. 221-228.
[14]. Owoeye I.O.G, Ibrahim .I.A Knowledge and attitude towards cervical cancer screening among female students and staff in a tertiary institution in the Niger Delta. International Journal of Medicine and Biomedical Research Volume 2. 2013. 48-56.

[15] Pengaruh Penyuluhan Sadari Terhadap Minat Wanita Usia Subur 20-45 Tahun Melakukan Pemeriksaan Payudara Sendiri (SADARI) Di Dusun Gumuk Ringin harjo Bantul [Skripsi]. Sekolah Tinggi Ilmu Kesehatan Aisyiyah Yogyakarta.2014.

[16]. Nugraheny, Esti. 2010. Pengaruh Pemberian Penyuluhan Terhadap Perilaku Untuk Melakukan Deteksi Dini Kanker Leher Rahim ditinjau dari Umur Pada Guru SMA di Kecamatan Sanden BantulYogyaKarta [Tesis]. Universitas Sebelas Maret Surakarta.

[17]. Safari. Evaluasi Pembelajaran. Departemen Pendidikan Nasional Direktorat Jendral Pendidikan Dasar dan Menengah Direktorat Tenaga Kependidikan 2003.

[18]. Spencer, F.R., \& Brown, P. Menopause. Jakarta: Erlangga.2006 